\title{
PEMIKIRAN HUKUM ISLAM IBNU TAIMIYYAH
}

\author{
Oleh: \\ Muhammad Syaikhon \\ Fakultas Keguruan dan Ilmu Pendidikan UNUSA \\ muhammadsay87@unusa.ac.id
}

\begin{abstract}
:
Ibn Taymiyyah was a reformer and medieval Islamic purifiers who had high authority. His thinking method was Salaf method which was based on the Qur'an and Hadis. The laws of fiqh that he often used leaned to the priest, imam Ahmad ibn Hanbal . Ushul fiqh method or Islamic legal thought of Ibn Taymiyah was Qur'an and Hadis , ijma' ' qiyas, istishab , and mashlahah mursalah .Thoughts of Ibn Taymiyyah can be classified into three types, namely: the same thinking by Imam Ahmad bin Hanbal, thoughts were not characterize a particular schools but according to Ibn Taymiyah 's own thoughts and ideas that are contrary to the opinions of Imam whole Islamic schools .
\end{abstract}

Key Words: Thought, Islamic Law, Ibn Taimiyyah

\section{A. Pendahuluan}

Dalam perjalanan sejarah, ajaran Islam mengalami penyimpanganpenyimpangan yang disebabkan oleh kesalahan dalam memahami dan mengamalkannya ataupun adanya penolakan masyarakat untuk menyesuaikan dengan prinsip-prinsip al-Qur'an dan al-Hadis yang benar, sehingga mendorong munculnya usaha-usaha pemurnian dan pembaharuan pemikiran Islam oleh pembaharu (mujaddid).

Dalam konteks makna dan hakikat pembaharuan (tajdid) dan kenyataan empirik yang terjadi polarisasi pemahaman Islam, sosok Ibn Taimiyyah adalah seorang pembaharu dan pemurni Islam abad pertengahan yang memilki otoritas tinggi. Sejarah telah mencatat bahwa Ibnu Tamiyyah bukan hanya sebagai pembaharu, tapi juga sebagai da'i yang tabah, wara', zuhud dan ahli ibadah, serta orang yang pemberani mengakkan kebenaran. Beliau adalah pembela tiap jengkal tanah umat Islam dari kezaliman musuh dengan pedangnya, seperti halnya beliau adalah pembela akidah umat dengan lidah dan penanya. 
Upaya yang dilakukan Ibnu Taimiyah berangkat dari asumsi dasar bahwa kaum Muslimin generasi pertama maju dengan pesat karena mereka berpegang kepada ajaran Islam dan menghormati al-Qur'an. Sebaliknya, kaum muslimin pada masanya lemah dan kurang dihargai komunitas agama lain karena mereka telah meninggalkan sumber ajarannya. Ia berkesimpulan bahwa tugas utama yang harus dijalankannya adalah menyeru umat Islam untuk kembali kepada al-Qur'an dan alSunnah, dengan menggunakan pemahaman kaum muslimin generasi pertama untuk menguji madzhab-madzhab dan hasil pemikiran kaum muslimin dari masa ke masa. ${ }^{1}$

\section{B. Pembahasan}

\section{Biografi Ibnu Taimiyah}

Nama lengkap Ibnu Taimiyyah ${ }^{2}$ adalah Ahmad Taqiy al-Din Abu al'Abbas ibn al-Shaikh Shihab al-Din Abi al-Mahasin 'Abd al-Halim ibn alShaikh Majid al-Din Abi al-Barokat 'Abd al-Salam ibn Abi Muhammad 'Abd Allah ibn Abi al-Qosim al-Khudr ibn Muhammad al-Khudr ibn 'Ali ibn 'Abd Allah. Ia lahir di kota Harran yang terletak di daerah Mesopotamia, pada hari senin, tanggal 10 Rabi'ul Awal 661 H / 22 Januari 1263 M. ${ }^{3}$ Sebagian ulama' menyebutkan bahwa beliau lahir tanggal 12 Rabi'ul Awal $661 \mathrm{H}$,

\footnotetext{
${ }^{1}$ Masyhud, Pemikiran Ibnu Taimiyah Tentang Metode Penafsiran Al-Qur'an Sebagai Upaya Pemurnian Pemahaman Terhadap Al-Qur'an, Jurnal Penelitian Agama,Vol. 9, No. 2 (Januari 2009), hlm. 36.

2 Suatu riwayat menyebutkan bahwa kakek Ibnu Taimiyyah pernah ditanya tentang asal-usul nama Taimiyyah. Dia menjawab bahwa ketika dia menunaikan ibadah haji ke Makkah, istrinya (nenek Ibnu Taimiyyah) sedang hamil dan ditinggalkan di rumah. Dalam perjalanan tepatnya di Taima' dekat Tabuk, tiba-tiba kakek Ibnu Taimiyyah melihat seorang gadis mungil lagi cantik yang muncul dari sebuah pintu gerbang. Ketika pulang dari menunaikan ibadah haji, dia diberitahu bahwa istrinya telah melahirkan bayi perempuan. Kabar gembira itu disambutnya dengan ucapan kesayangan seraya memanggil anak bayinya dengan ucapan" Ya Taimiyyah! Ya Taimiyyah!". Jadi nama Taimiyyah dinisbatkan kepada gadis cantik yang ditemui di dusun Taima' tersebut. Riwayat lain menyebutkan bahwa nama Taimiyyah dinisbatkan kepada nenek moyang Ibnu Taimiyyah, yakni datuknya yang bernama Abu Muhammad 'Abd Allah ibn al-Khudr, mempunyai seorang ibu yang sering memberinya nasihat. Seorang ibu itu bernama Taimiyyah. Jadi kepada Taimiyyah inilah keluarga besar Ibnu Taimiyyah dinisbatkan. Lihat Muhammad Abu Zahrah, Ibnu Taimiyyah Hayatuhu wa 'Ashruhu, Arauh wa Fiqhuh, (Kairo: Dār al-Fikr , 2000), hlm. 17. Lihat pula Muhammad ibn Ali al-Shaukani, Nail alAushar Sharh Muntaq al-Akhbar, Juz 1, (Beirut: Dār al-Jail, 1995), hlm. 4-5.

3 Muhammad Sayyid Jalil, al-Imam Ibnu Taimiyyah wa Mauqifuhu Min Qodiyati alTa'wil, (Kairo: al-Jam'iyah al-'Ammah li Shu'uni al-Matabi' al-Amiriyah, 1972), hlm. 15.
}

$340 \mid$ JURNAL LISAN AL-HAL 
karena mereka bermaksud menetapkan tanggal kelahiran Ibnu Taimiyyah itu bertepatan dengan kelahiran Nabi Muhammad SAW. yang akan meneruskan perjuangannya. ${ }^{4}$

Adapun ayah Ibn Taimiyyah, Shihab al-Din Abi al-Mahasin 'Abd alHalim ibn al-Shaikh Majid al-Din Abi al-Barokat 'Abd al-Salam yang lahir di Harron $627 \mathrm{H}$, banyak mendengarkan ilmu dari sang ayah dan juga ulama' yang lain. Sampai ia pun mampu menguasai ilmu-ilmunya dengan baik dan menjadi seorang ulama', khotib dan juga hakim di kotanya. ${ }^{5}$

Begitu pula kakeknya, Shaikh Majid al-Din Abu al-Barokat 'Abd alSalam adalah seorang ulama' fiqih madzhab hanbali, ahli tafsir, hadith, ushul dan nahwu. Beliau juga seorang hafidz al-Qur'an. Shaikh Majidduddin seorang pecinta ilmu. Beliau tidak puas menimba ilmu di kotanya sendiri. Sehingga pada tahun $603 \mathrm{H}$, ia pun pergi ke Baghdad untuk menambah ilmu dan pengetahuannya. Setelah 6 tahun di Baghdad, syaikh majidduddin kembali ke Harran dan menjadi seorang ulama' besar yang dihormati banyak orang. 6

Ketika Ibnu Taimiyyah berumur 6 tahun dunia Islam Timur tengah diserang oleh pasukan Tartar, sehingga kota Baghdad jatuh di tangan mereka dan banyak orang yang melarikan diri. Dia dibawa lari oleh ayahnya bersama kedua saudaranya ke Damaskus. Di tengah perjalanan, hampir saja mereka tertangkap oleh pasukan Tartar, untungnya mereka bisa selamat dan bisa sampai tujuan. ${ }^{7}$

Di Damaskus, suatu kota yang penuh dengan ulama' dan pusat ilmu pengetahuan, Ibnu Taimiyyah berkembang dan maju dengan pesatnya. Suatu kelebihan yang diberikan Ibnu Taimiyyah adalah cepat hafal dan sukar lupa. Para sahabat, murid dan ulama' seangkatnya sama-sama mengakui kemampuan hafalannya. Sebagian mengatakan bahwa tak sehuruf pun dari al-Qur'an maupun hadith atau sesuatu ilmu yang dia hafal lalu lupa. ${ }^{8}$

Dalam usia 7 tahun dia sudah hafal al-Qur'an dengan amat baik dan lancar. Selain itu, penguasannya yang prima terhadap berbagai ilmu yang diperlukan untuk memahami al-Qur'an menyebabkan ia tampil sebagi ahli

${ }^{4}$ Muhammad Abu Zahrah, Tārīkh al-Madzāhib al-Fiqhiyyah, (Kairo: Ma'had alDirāsāt al-Islamiyyah, tt.), hlm. 442.

5 Muhammad Yusuf Musa, Ibnu Taimiyyah, (Kairo: al-Mu'assasah al-Masriyah al‘Āmmah,1962), hlm. 66.

${ }^{6}$ Ibid., hlm. 67.

${ }^{7}$ Ahmadie Thaha, Ibnu Taimiah Hidup dan Pemikirannya, (Surabaya: PT Bina Ilmu Offset, 2007), hlm. 10.

8Ibid., hlm. 11. 
tafsir, di samping juga ahli hadith. Keahliannya dalam bidang hadith ini tampak terlihat sejak masa kecil. Suatu ketika, salah seorang gurunya mendiktekan 11 matan hadith kepadanya. Ketika ia disuruh mengulang hadith tersebut, ia telah menghafalnya dengan baik. ${ }^{9}$

Dalam berbagai pertemuan, kuliah umum, dan pengajian, dia selalu hadir meskipun masih muda dan berkumpul bersama para orang tua. Bahkan dalam berbagai kesempatan dia mengadakan dialog dan berdiskusi dengan para ulama'. Pada usia 17 tahun kegiatan ilmiahnya sudah mulai memberikan fatwa-fatwa dan mengarang. Dalam umur 21 tahun dia ditinggal pergi oleh ayahnya. Dia begitu sedih. Namun kesedihannya dia palingkan pada suatu pekerjaan yang besar, yaitu menafsirkan al-Qur'an.10

Kamaluddin bin al-Zamlakani dalam salah satu tulisannya mengatakan bahwa jika ahli-ahli fiqh yang datang dari berbagai madzhab duduk bersamanya, mereka akan banyak memperoleh ilmu tentang madzhabnya yang tidak diketahui dari Ibnu Taimiyyah. Tak pernah sekali saja dia berdiskusi dengan seseorang lalu dia kalah. Dalam hal tulis menulis, dia begitu indah memilih kata-kata, paparannya tepat pada sasaran, pandai menyusun kerangka dan kata-kata. ${ }^{11}$

Banyak orang yang menulis riwayat hidup Ibnu Taimiyyah dan juga memujinya. Mereka menjelaskan bahwa Ibnu Taimiyyah telah mengerahkan seluruh tenaganya untuk mencari ilmu dengan berbagai cabangnya. Dalam berbagai ilmu pengetahuan, dia berada di depan di antara para ulama' yang ada dan hidup pada zamannya.

Selain menulis, aktivitas ilmiah yang paling dia tekuni kurang lebih 20 tahun adalah mengajar dan memberi fatwa-fatwa. Hal ini ia lakukan semenjak kurang dari usia 20 tahun $^{12}$. Kematian ayahnya pada tahun 682 merupakan cambuk baginya untuk terus melaksanakan cita-cita ayahnya. Dia mengajar dan memberi fatwa-fatwa lebih tekun lagi, meskipun umurnya belum lagi 21 tahun.

Ibnu Taimiyyah merupakan figur dari ulama' yang terkenal keberaniannya, sabar dan pemaaf. Sejarah telah mencatat berbagai kejadian penting yang menyatakan tentang keberanian Ibnu Taimiyyah

${ }^{9}$ Abdul Azis Dahlan dkk, Ensiklopedi Hukum Islam, (Jakarta: PT Ichtiar Baru van Hoeve, 2003), hlm. 624.

${ }^{10}$ Ahmadie Thaha, Ibnu Taimiah Hidup dan Pemikirannya, (Surabaya: PT Bina Ilmu Offset, 2007), hlm. 12.

11 Ibid., hlm. 13.

12 Ibid., hlm. 14.

$342 \mid$ JURNAL LISAN AL-HAL 
dan kekerasannya dalam jihad fi sabilillah terutama melawan para ahli bid'ah dan khurafat.

Pemikiran Ibnu Taimiyyah sering menjadi ajang polemik di kalangan para ulama', sejak zaman Ibnu Taimiyyah sendiri, dan gara-gara itu dia sering keluar masuk penjara, terutama mengenai masalah-masalah akidah dan fiqh. Keberanian Ibnu Taimiyyah ini tidak hanya berbeda dengan para ulama di zamannya, namun Ibnu Taimiyah juga sering menyalahi ijma". Itulah yang membuat ulama' di zamannya geram pada Ibnu Taimiyyah. Akhirnya Ibnu Taimiyyah dituduh sesat dan dipenjara.

Mula-mula meskipun dipenjara Ibnu Taimiyyah masih dapat meneruskan kegiatan ilmiahnya dengan menulis buku atau makalah, tetapi kemudian jiwanya sangat terpukul ketika dipenjara Damaskus ia tidak diberi kertas dan tinta lagi. Dia tidak tahan menerima penghinaan itu, dan akhirnya tutup usia pada tahun $728 \mathrm{H}$ atau $1329 \mathrm{M}$, pada usia lebih kurang 66 tahun. ${ }^{13}$

\section{Perjalanan Intelektual Ibnu Taimiyyah}

Sejak kecil, Ibnu Taimiyyah memulai belajarnya dengan mendalami al-Qur'an dan hadith kepada sang ayah. Karena adanya serangan pasukan Tatar ke negerinya Syam (Syiria), ia dan keluarganya pindah ke Damaskus. Kota ini termasuk salah satu pusat ilmu tebesar pada masa itu. Ibnu Taimiyyah seorang anak yang cerdik, hari-harinya ia sibukkan untuk belajar. Ibnu Wardi mengatakan bahwa setelah ia mengusai ilmu khot, hisab (hitung), dan hafalan qur'an, dengan segera ia mempelajari ilmu fiqih dan bahasa arab sampai ia pun unggul dalam ilmu nahwu. Setelah itu, ia bergegas mempelajari ilmu tafsir secara keseluruhan sampai selesai. Kemudian ia melanjutkan ke ilmu ushul fiqh. Semua itu dilakukan oleh anak usia sekitar 10 tahun. ${ }^{14}$ Dengan kecerdasan dan ketekunannya ia mampu mendalami berbagai macam ilmu agama,termasuk ilmu kalam dan filsafat dalam usia 19 tahun. Dan ia telah dipercaya untuk mengeluarkan fatwa. Ketika menginjak usia 21 tahun, ia menggantikan kedudukan ayahnya yang telah meninggal sebagai seorang ulama' dan hakim. Demikian Ibnu Taimiyyah tumbuh menjadi ulama' besar terkemuka dan berpandangan luas. Keulamaannya mencakup seluruh kajian keislaman sehingga pantas mendapat gelar Syaikhul Islam. Pada usia 30 tahun, usia yang relatif masih muda, Ibnu Taimiyyah sudah diakui kapasitasnya

13 Munawir Sjaddzali, Islam dan Tata Negara, (Jakarta: UI-Press, 2003), hlm. 82.
14 Jalil, al-Imam, hlm. 70. 
sebagai ulama' besar pada zamannya. ${ }^{15}$

Di antara guru-guru Ibnu Taimiyyah, selain dari kalangan keluarganya, adalah sebagai berikut : 16

a. Ibnu 'Abd al-Qawi (603-699 H.). Nama lengkapnya adalah Muhammad ibn 'Abd al-Qawi ibn Badran ibn 'Abd Allah al-Maqdisi, julukannya (laqab ) Syams al-Din, dan nama panggilannya (kunyah) Abu 'Abd Allah. Ia ahli dalam bidang hadith, fiqh, dan bahasa Arab. Di antara kitab yang disusunnya adalah al-Furuq.

b. Ibn 'Abd al-Da'im (577-678 H.). Nama lengkapnya adalah Ahmad ibn 'Abd Da'im ibn Ni'mah ibn Ahmad ibn Muhammad ibn Ibrahim ibn Ahmad ibn Bakr al-Maqdisi. Ibnu Taimiyyah berguru hadith kepadanya. Di antara ulama yang meriwayatkan hadith dari Ibn 'Abd al-Da'im adalah al-Syaikh Muhy al-Din al-Nawawi dan Ibn Daqiq al-'Id.

c. Al-Munaja' ibn Uthman al-Tanukhi (611-195 H.). Beliau adalah seorang faqih yang terkenal di Syam (Suriah) pada zamannya. Di samping itu, ia dikenal sebagai ulama yang ahli dalam bidang tafsir dan bahasa Arab. Di samping mengajar, kegiatannya adalah menulis. Di antara tulisannya adalah Sharh al-Mughni (empat jilid), Tafsir al-Qur'an, dan Ikhtishar al-Mahshul. Ibnu Taimiyyah belajar fikih kepadanya.

d. Ibnu Qudamah (597-682 H.). Nama lengkapnya adalah 'Abd al-Rahman ibn Muhammad ibn Ahmad ibn Qudamah al-Maqdisi. Ia adalah pemimpin madzhab yang cemerlang pada masanya.

Dari gambaran di atas, dapatlah diketahui bahwa selain karena kepandaian, kecerdasan, dan ketekunan, kealiman Ibnu Taimiyyah terdukung oleh situasi lingkungannya, sehingga ia menjadi ulama' yang giat mengajarkan ilmu-ilmunya.

Sebagai seorang ulama' yang sangat cerdas, Ibnu Taimiyyah banyak mencurahkan perhatiannya untuk pengembangan ilmu agama. Hal ini dapat dibuktikan dari karya-karya yang didasilkan dan murid-muridnya. Di antara beberapa murid Ibnu Taimiyyah adalah sebagai berikut : ${ }^{17}$

a. Ibnu Qayyim al-Jauziyyah (w.751 H.). Nama lengkapnya adalah Muhammad ibn Abi Bakr ibn Ayyub ibn Sa'ad ibn Harith al-Zar'i alDimashqi Abu 'Abd Allah, julukannya adalah Syams al-Din. Ia lebih dikenal dengan nama Ibnu Qayyim al-Jauziyyah. Karyanya tidak kurang

${ }^{15}$ Dewan Redaksi Ensiklopedi Islam, Ensiklopedi Islam, (Jakarta : PT Ichtiar Baru van Hoeve, 2000), hlm. 169.

${ }^{16}$ Jaih Mubarok, Sejarah dan Perkembangan Hukum Islam, (Bandung: PT Remaja Rosdakarya, 2000), hlm. 171-172.

17 Ibid., hlm. 172-173.

344 JURNAL LISAN AL-HAL 
dari 41 judul. Di antara kitabnya yang banyak dijadikan rujukan adalah I'lam al-Muwaqqi'in 'an Rabb al-'Alamin. Kaidah fiqh yang dibangunnya hingga sekarang ini masih dijadikan rujukan, yaitu, kaidah "taghayyur al-fatwa bi hasab taghayyur al-azminah wa al-amkinah wa al-ahwal wa al-niyyat wa al-awa'id".

b. Al-Dzahabi (701-748 H.). Nama lengkapnya adalah Syams al-Din Abi 'Abd Allah Muhammd ibn Ahmad ibn Uthman ibn Qaimaz alTurkumani al-Dzahabi. Di antara kitabnya yang terkenal adalah alTafsir wa al-Mufassirun dan al-Hadith wa al-Muhaddithun.

c. Ibnu Kathir (701-744 H.). Nama lengkapnya adalah 'Imad al-Din Isma'il ibn 'Umar ibnu Kathir. Di antara karyanya yang terkenal adalah Tafsir Ibn Kathir.

d. Al-Thufi (lahir tahun 670-an). Nama lengkapnya adalah Sulaiman ibn 'Abd al-Qawi ibn Sa'id al-Thufi. Ia dikenal sebagai seorang penganut Syi'ah yang bermadzhab Hanbali.

\section{Karya-karya Ibnu Taimiyyah}

Profesinya sebagai seorang penulis ditekuninya sejak usia 20 tahun. Tulisan-tulisannya banyak bernada kritik terhadap segala pendapat dan paham yang tidak sejalan dengan pemikirannya, karena menurutnya bertentangan dengan ajaran al-Qur'an dan hadith.

Abu Hasan 'Ali al-Nadwi menyimpulkan bahwa ada 4 macam keistimewaan yang ada di dalam karya-karya Ibnu Taimiyyah. Pertama, karya-karyanya memberi kesan kepada pembacanya bahwa dia adalah seorang yang memahami tujuan-tujuan syari'at dan ruh agama. Hal ini berkaitan dengan penguasaannya yang sangat mendalam tentang berbagai sisi dan dasar-dasar agama. Kedua, karya-karyanya terasa hidup dan dinamis karena pada umumnya ditulis untuk merespon pertanyaanpertanyaan yang diajukan kepadanya ataupun dalam rangka mengkritisi suatu masalah yang berkembang. Ketiga, terkesan padat isi dan penuh keseriusan. Hal ini bisa dilihat dari kebiasaannya yang selalu memberi rujukan bagi pandangan-pandangannya baik pada al-Qur'an, al-Hadith, maupun pendapat-pendapat para ulama' khususnya ulama' salaf. Keempat, pada umumnya ditulis dengan bahasa yang luas dan tegas. ${ }^{18}$

Sementara itu, Nur Cholish Madjid berkomentar bahwa sebagian besar karyanya ditulis dalam suasana dan gaya bahasa yang sangat polemis karena menghadapi berbagai pihak yang menurut pandangannya

18 Abu al-Hasan Ali al-Husni al-Nadwi, Rijall al-Fikr wa al-Da'wah fi al-Islām, (Kuwait: Dār al-Qalam, 1983), hlm. 133-135. 
telah menyeleweng dari ajaran Islam yang benar. Di sisi lain, sangat kritis, analitis, polemis, hiperbolis dan bombastis, namun menunjukkan kelebihan yang mengagumkan dalam penguasaan atas bahan pemikiran Islam, disertai kesadaran historis yang luas dan mendalam. ${ }^{19}$

Adapun karya-karyanya kurang lebih mencapai 500 jilid. Di antara karyanya tersebut yang terkenal adalah :

a. Kitab al-Radd 'ala al-Manthiqiyyin (jawaban terhadap para ahli mantiq)

b. Manhaj al-Sunnah al-Nabawiyyah (metode sunnah nabi)

c. Majmu' al-Fatawa (kumpulan fatwa)

d. Bayan Muwafaqat Shahih al-Ma'qul Sharih al-Manqul (uraian tentang kesesuaian pemikiran yang benar dan dalil naqli yang jelas)

e. Al-Radd 'ala Hululiyyah wa al-Ittihadiyyah (jawaban terhadap paham hulul dan ittihad)

f. Muqaddimah fi Usul al-Tafsir (pengantar mengenai dasar-dasar tafsir)

g. Al-Radd 'ala Falsafah ibn Rushd (jawaban terhadap falsafah ibn rusyd)

h. Al-Iklil fi al-Mushabahah wa al-Ta'wil (suatu pembicaraan mengenai ayat mutasyabih dan ta'wil)

i. Al-jawab al-Sahih li Man Baddala Iman al-Masih (jawaban yang benar terhadap orang-orang yang menggantikan iman terhadap al masih)

j. Al-Radd 'ala al-Nusairiah (jawaban terhadap paham nusairiah)

k. Risalah al-Qubrusiyyah (risalah tentang paham qubrusiyah)

l. Ithbat al-Ma'ad (menentukan tujuan)

m. Thubut al-Nubuwwat (eksistensi kenabian)

n. Ikhlas\} al-Ra'i wa Ra'iyat (keikhlasan pemimpin dan yang dipimpin)

o. Al-Siyasah al-Shar'iyyah fi Ishlah al-Ra'i wa al-Ra'iyah (politik yang berdasarkan syari'ah bagi perbaikan penggembala dan gembala). Kitab ini merupakan kitab yang sangat penting, karena di dalam kitab ini menunjukkan bahwa tujuan gerakan Ibnu Taimiyyah adalah memperbaiki moral dan sosial dari segala kerusakan sebagai akibat dari malapetaka yang menimpa umat Islam karena perang dengan Krusades dan juga serbuan dari bangsa Tatar. ${ }^{20}$

Masih banyak lagi buah pena yang dihasilkan. Karangankarangannya hampir semua berisikan kritik terhadap segala paham aliranaliran agama Islam yang menurutnya tidak sesuai dengan al-Qur'an dan al-

19 Nur Cholish Madjid, Kaki Langit Peradaban Islam, (Jakarta: Paramadina, 1997), hlm. 127-130.

${ }^{20}$ Munawir Sjaddzali, Islam dan Tata Negara, (Jakarta: UI-Press, 2003), hlm. 82.

346 JURNAL LISAN AL-HAL 
Sunnah. ${ }^{21}$

\section{Metode Pemikiran Hukum Islam Ibnu Taimiyyah}

Metode berfikir Ibnu Taimiyyah secara rinci dapat dilihat dalam bukunya Majmu' al-Fatawa (kumpulan fatwa-fatwa). Dalam buku ini, nampak sekali komitmen Ibnu Taimiyyah sebagai orang yang kuat berpegang pada salaf. Metode berfikirnya adalah metode salaf yang bersumber pada al-Qur'an dan hadith. Karena itu, pendapat-pendapatnya sarat dengan al-Qur'an dan hadith. ${ }^{22}$

Setiap ahli fiqh dari keempat imam madzhab yang sudah kita kenal, masing-masing mempunyai dasar-dasar pokok sebagai sandaran dan tempat kembalinya di dalam pengambilan hukum. Ibnu Taimiyyah bukanlah imam madzhab yang mempunyai dasar-dasar pokok, sebagaimana keempat madzhab (Hanafi, Maliki, Syafi'i, dan Hanbali). Hukum-hukum fiqh yang ia istinbatkan bersandar kepada imam madzhabnya, yaitu imam Ahmad bin Hanbal. ${ }^{23}$

Menurut penyelidikan para sarjana ushul, fatwa-fatwa Imam Ahmad bin Hanbal didasarkan atas dalil-dalil hukum meliputi:24

a. Nash, yakni al-Qur'an dan hadith sebagai sumber hukum yang utama dan pertama. Ia tidak membedakan antara derajat al-Qur'an dan hadith sebagai sumber hukum Islam.

b. Fatwa sahabat, yaitu fatwa-fatwa para sahabat Nabi, terutama yang mereka sepakati. Jika imam Amad bin Hanbal mendapatkan fatwa sebagian sahabat dan tidak mengetahui adanya sahabat lain yang menyalahi fatwa tersebut, ia tidak akan berpaling pada yang lain. Ia tidak mau menyebut fatwa-fatwa sahabat tersebut sebagai ijma', tetapi karena hati-hati, ia lebih senang mengungkapkannya dalam kata-kata la a'lam shai'an yadfa'uhu (aku tidak mengetahui adanya seseorang yang menolaknya) atau dalam ungkapan-unkapan lain yang senada.

c. Hadith mursal dan hadith da'if. Ahmad bin Hanbal mengambil hadith mursal dan hadith da'if sebagai dasar penetapan hukum bagi suatu masalah selama tidak bertentangan dengan nash-nash al-Qur'an dan hadith yang sahih serta fatwa para sahabat. Adapun yang dimaksud

\footnotetext{
21 Dewan Redaksi Ensiklopedi Islam, Ensiklopedi Islam, (Jakarta : PT Ichtiar Baru van Hoeve, 2000), hlm. 169.

22 Ibid., hlm. 170.

23 Muhammad Yusuf Musa, Ibnu Taimiyyah, (Kairo: al-Mu'assasah al-Masriyah al'Āmmah,1962), hlm. 168.

24 Abdul Azis Dahlan dkk, Ensiklopedi Hukum Islam, (Jakarta: PT Ichtiar Baru van Hoeve, 2003), hlm. 625.
} 
hadith da'if dalam pandangan imam Ahmad bin Hanbal bukanlah hadith yang batil dan mungkar, melainkan apa yang dikenal dengan sebutan hadith hasan dalam istilah ilmu hadith.

d. Qiyas (analogi). Imam Ahmad bin Hanbal menggunakan qiyas sebagai dasar penetapan hukum dalam keadaan terpaksa, yaitu apabila ia menghadapi suatu persoalan yang dasar hukumnya tidak ditemukan di dalam al-Qur'an atau sunnah, tidak pula dijumpai dalam fatwa para sahabat atau salah satu dari mereka, atau tidak ada hadith mursal atau hadith da'if.

Meskipun secara umum ushul fiqh Ibnu Taimiyyah sama dengan ushul fiqh Imam Ahmad bin Hanbal. Dalam beberapa hal, ada perbedaan antara keduanya. Perbedaan-perbedaab tersebut adalah sebagi berikut: 25

a. Ibnu Taimiyyah meletakkan hadith sebagai sumber hukum kedua setelah al-Qur'an. Sedangkan Imam Ahmad bin Hanbal fatwa sahabat sebagai sumber hukum kedua setelah al-Qur'an dan sunnah.

b. Ibnu Taimiyyah meletakkan ijma' sebagai sumber hukum yang ketiga. Sedangkan sumber hukum yang ketiga bagi Imam Ahmad bin Hanbal adalah hadith mursal dan hadith da'if. Ditempatkannya ijma' pada urutan ketiga oleh Ibnu Taimiyyah bukan tanpa alasan. Ia merujuk pada beberapa asar para sahabat Nabi, di antaranya ucapan Umar bin alKhattab yang berkata "Putuskanlah perkara itu menurut hukum yang ada dalam Kitab Allah. Kalau tidak ada (dalam al-Qur'an), putuskanlah sesuai dengan sunnah Rasul, dan kalau tidak ada (dalam sunnah Rasul), putuskanlah berdasarkan hukum yang telah disepakati oleh umat manusia".

c. Sumber hukum yang keempat yang digunakan oleh Ibnu Taimiyyah adalah qiyas. Ibnu Taimiyyah membagi qiyas dalam dua macam, yaitu qiyas sahih (analogi yang didasarkan pada persamaan illat yang jelas) dan qiyas fasid (analogi yang didasarkan pada illat yang dibuat-buat).

Selanjutnya Dr. Muhammad Yusuf Musa dalam bukunya yang berjudul Ibnu Taimiyyah menyebutkan bahwa ushul fiqh yang mewarnai fiqh dan hukum-hukum syar'i yang diambil oleh Ibnu Taimiyyah adalah sebagai berikut: 26

${ }^{25}$ Ibid., hlm. 626.

${ }^{26}$ Muhammad Yusuf Musa, Ibnu Taimiyyah, (Kairo: al-Mu'assasah al-Masriyah al'Āmmah,1962), hlm. 168-222.

348 JURNAL LISAN AL-HAL 
a. Kitab dan Sunnah: Al-Qur'an dan hadith merupakan sumber utama dari pengambilan hukum Islam. Mengenai hadith, Ibnu Taimiyyah membaginya menjadi tiga macam:

Pertama: Sunnah Mutawatirah, yaitu sunnah Rasul yang menafsirkan al-Qur'an dan tidak bertentangan dengan dhahirnya. Misalnya, mengenai jumlah shalat fardhu dan rakaatnya sehari semalam, ukuran nisab zakat, manasik haji, dan lain sebagainya.

Kedua: Sunnah Mutawatirah tetapi tidak menjadi tafsiran dari alQur'an, atau yang pada dhahirnya bertentangan dengannya, tapi membawa hukum baru, seperti hadith-hadith yang mendatangkan hukum baru yang tidak terdapat dalam nash, tapi tidak bertentangan pada dhahirnya. Misalnya, nisabnya mencuri, rajamnya bagi pezina, dan lain sebagainya.

Ketiga: khabar ahad yang sampai kepada kita melalui riwayat-riwayat yang kuat (thiqat) dari riwayat-riwayat yang kuat pula. Ibnu Taimiyyah menganggap ini sebagai hujjah atau salah satu dalil pokok dari ushul fiqh.

Ibnu Taimiyyah benar-benar memperhatikan sunnah dan mengamalkannya sebaik mungkin jika ia shahih, meskipun hadith itu berupa khabar ahad. Menurut Ibnu Taimiyyah, menolak hadith tersebut berarti menentang keumuman al-Qur'an maupun dhahirnya. Pendapat ini senada dengan Abu Hanifah, dan Imam Malik yang juga menambahkan bahwa menolak hadith tersebut berarti menentang praktek penduduk Madinah.

b. Ijma': yang disepakati oleh seluruh kaum muslimin adalah ijma' yang dilakukan oleh para sahabat. Ijma' yang dilakukan oleh ulama'-ulama' selain mereka keabsahannya diragukan. Sebab itu tidak bisa dijadikan dasar hukum.

Mengenai ijma' yang datang setelah para sahabat ini, Ibnu Taimiyyah berpendapat bahwa jika para ulama' ijma' atas suatu hukum, maka tak seorang pun boleh keluar dari ijma' itu karena suatu umat tidaklah berijma' atas sesuatu kesesatan. Namun Ibnu Taimiyyah tak berhenti sampai di situ, ijma' itupun harus mempunyai sandaran kembali dari nash al-Qur'an dan hadith. Ijma' yang seperti inilah yang dia anggap patut dijadikan salah satu hujjah atau dalil hukum.

Bagaimana jika terjadi pertentangan antara ijma' dengan nash yang datang dari Rasulullah, apakah ijma' itu yang diambil dan menjadi nasikh bagi nash? Atau mengambil nashnya dan meninggalkan hukum yang berdasar ijma'?.

Menurut Ibnu Taimiyyah mustahil ada ijma' yang bertentangan 
dengan nash Rasul. Jika memang ada nash yang bertentangan dengan ijma' maka di samping ijma' itu pasti ada nash lain yang menerangkan penghapusan nash yang pertama.

Dalam kitab Ma'arij al-Wushul, Ibnu Taimiyyah menerangkan bahwa sunnah tidak pernah menasakh hukum yang telah ditetapkan alQur'an, sebagaimana sunnah tak pernah dinasakh oleh ijma'.

c. Qiyas: yang dimaksud di sini adalah qiyas yang shahih yang sesuai dengan nash, pernah dilakukan oleh sahabat dalam pengambilan hukum, dan dinyatakan oleh Rasulullah serta menanggapi kebenarannya sewaktu beliau hidup dan melihat ada sahabat yang melakukannya.

Dalam risalahnya, Ibnu Taimiyyah menerangkan tentang qiyas yang benar, bentuk dan syarat yang harus dimiliki dan didapat dalam qiyas itu, yaitu:

Pertama: 'Illat hukum tasyri' yang terdapat dalam asal harus juga ada di dalam cabang (furu'), tanpa ada pertentangan dalam cabang yang menjadi penyebab terlarang penentuan hukum 'illah itu.

Kedua: Qiyas dengan pembatalan pembeda antara dua bentuk itu (asal dan cabang). Antara keduanya, asal dan cabang tidak boleh ada pembeda yang mempengaruhi syara'.

Menurut Ibnu Taimiyyah, qiyas yang shahih adalah qiyas yang sejalan dengan nash. Nash tak pernah bertentangan dengan qiyas. Sedangkan qiyas yang salah bisa bertentangan dengan nash. Dalam syari'at tak ada suatu perkara yang bertentangan dengan qiyas.

d. Istishab: Menurut Ibnu Taimiyyah, istishab adalah tetap berpegang pada hukum asal, selama hukum itu belum diketahui tetap ada atau sudah diubah menurut syara'. Ia adalah hujjah bagi ketidak-adaan ittifaq.

Jika seorang mujtahid dihadapkan pada suatu masalah yang sedang hangat terjadi di masyarakatnya, kemudian dia diminta pendapatnya, dan tidak mendapatkan nash dari al-Qur'an hukum masalah itu, mubah atau haram, maka dia harus memilih mubahnya, sebab asal dari segala sesuatu itu mubah, kecuali yang sudah diharamkan oleh syara'. Ibahah atau pembolehan itu merupakan keadaan yang keseluruhan ciptaan Allah yang ada di atas bumi. Jika tak ada hukum syara' yang menentukan perubahan ibahah itu, maka ia pun tetap berada dalam hukum mubah (hukum asal).

e. Mashlahah Mursalah: Ibnul Qayyim, murid Ibnu Taimiyyah, benarbenar memberikan perhatiannya yang tidak sedikit kepada fiqh imam

$350 \mid$ JURNAL LISAN AL-HAL 
Ahmad bin Hanbal. Namun ketika berbicara mengenai ushul fiqh, dia tidak membicarakan masalah maslahah mursalah, padahal madzhabmadzhab yang lain membicarakannya.

Namun dalam salah satu buku yang membicarakan tentang usul fiqh, Ibnu Taimiyyah membicarakan pula maslahah mursalah. Namun dia ragu-ragu mengenai hakikat dan kebenarannya, dan ragu-ragu menerimanya. Hal ini dikarenakan pada masanya penuh dengan berbagai aliran pemikiran sesat, filsafat dan sufi, serta arus pemikiran lain yang menentang Islam. Sebagian sultan dan raja mempergunakan pakain tertentu dengan maksud dan keyakinan dapat menolak bahaya yang datang, dan lain sebagainya.

Jumhur ulama' menolak maslahah mursalah secara mutlak. Cuma Imam Malik yang menerimanya secara mutlak. Hal ini sebenarnya cukup mengherankan, sebab Ibnu Taimiyyah, Ibnul Qayyim, samasama menetapkan ushul hukum maslahah mursalah ini dalam berbagai ketetapan hukum fiqh, seperti dapat kita baca dari kitabkitabnya.

\section{Pro dan Kontra atas Pemikiran Ibnu Taimiyyah}

Ibnu Taimiyyah banyak mengetahui masalah fiqh Islam dari berbagai madzhab yang ada. Bahkan ada yang mengatakan bahwa pengetahuannya tentang fiqh berbagai madzhab lebih luas dan mendalam daripada pengetahuan penganut-penganut madzhab itu sendiri. Ia memahami dengan mendalam perbedaan pendapat ulama', mengetahui masalah-masalah ushul dan furu'. Pengetahuannya tentang fiqh itu juga di barengi penguasaan yang mendalam terhadap ushul fiqh. Hal ini terlihat dengan kesanggupannya untuk tampil sebagai mufti sejak berumur 20 tahun.

Telah kita ketahui bahwa Ibnu Taimiyyah adalah pengikut madzhab Hanbali. Namun dalam berbagai pendapat fiqh dan ushulnya kita temukan ketidaksamaannya dengan pendapat imamnya. Oleh karena itu pantaslah kalau dia disebut mujtahid baru. Kamaluddin bin al-Zamlakani sebagai seorang ulama' di masanya juga mengatakan bahwa Ibnu Taimiyyah telah memenuhi syarat-syarat ijtihad. ${ }^{27}$

Ibnu Taimiyyah mempunyai banyak sekali pendapat tentang hukum Islam. Jika diklarifikasikan, maka pendapat-pendapatnya itu dapat

27 Ahmadie Thaha, Ibnu Taimiah Hidup dan Pemikirannya, (Surabaya: PT Bina Ilmu Offset, 2007), hlm. 100. 
kita bagi dalam tiga golongan: ${ }^{28}$

a. Pendapat-pendapat yang berisikan pendapat Imam Ahmad bin Hanbal.

b. Kumpulan pendapat yang tidak mencirikan suatu madzhab tertentu, tapi menurut pemikiran Ibnu Taimiyyah sendiri.

c. Pendapat-pendapat yang bertentangan dengan pendapat-pendapat keseluruhan Imam madzhab Islam.

Penyusunan pendapatnya ke dalam tiga klarifikasi ini merupakan suatu hal yang biasa dilakukan oleh seorang manusia, di mana pada masamasa permulaannya masih begitu setia dengan imam madzhabnya, sehinga pikiran-pikiran sang imam menjadi panutan, namun setelah lama pikiran-pikiran imamnya itu, dia pun mengetahui kekurangan-kekurangan yang dimiliki sang imam. Pada fase berikutnya dia pun menulis dengan ciri tersendiri, dan tidak heran kalau menyerang pendapat-pendapat yang menyerangnya.

Berikut ini adalah pendapat-pendapat Ibnu Taimiyyah yang berhubungan dengan masalah fiqh:

a. Kedewasaan sebagai penghapus hak ijbar ${ }^{29}$

Dalam salah satu hadith dikatakan bahwa Nabi Muhammad SAW. bersabda:"الايم احق بنفسها من وليها" . Dari hadith ini, para ulama' di antaranya Daud al-Zhahiri berpendapat bahwa wali mempunyai hak ijbar (memaksa) terhadap anak gadis, dan tidak mempunyai hak ijbar terhadap anak yang sudah janda.

Ibnu Taimiyyah tidak sependapat dengan pandangan di atas yang antara lain dikemukakan oleh imam al-Zhahiri. Menurut Ibnu Taimiyyah. Hak ijbar tidak terletak pada kegadisan dan kejandaan, meskipun dalam hadith secara eksplisit dikatakan janda (al-ayyim), tetapi pada kedewasaan. Oleh karena itu hak ijbar wali akan hilang apabila anak yang akan dinikahkannya sudah dewasa, baik ia masih gadis maupun sudah pernah menikah. Sebaliknya, sekalipun ia pernah menikah tetapi belum dewasa, wali masih memiliki hak ijbar terhadapnya. Kata al-ayyim tidak dipahaminya secara tekstual. Ia memahaminya sebagai kedewasaan berfikir.

b. Pengangkatan pemimpin termasuk kewajiban agama ${ }^{30}$

Dalam kitab al-Siyasah al-Shar'iyyah fi Islah al-Ra'i wa al-Ra'iyyah,

\footnotetext{
28 Ibid., hlm. 100.

${ }^{29}$ Jaih Mubarok, Sejarah dan Perkembangan Hukum Islam, (Bandung: PT Remaja Rosdakarya, 2000), hlm.173-174.

30Ibid., hlm. 174-175.
}

$352 \mid$ JURNAL LISAN AL-HAL 
Ibnu Taimiyyah mengatakan bahwa mengangkat pemimpin merupakan salah satu kewajiban agama. Sebab kemaslahatan manusia tidak akan sempurna kecuali bermasyarakat yang antara satu dengan yang lainnya saling memerlukan. Karena bermasyarakat, manusia wajib menjadikan salah seorang di antara mereka sebagai pemimpin. Sabda Nabi:

$$
\text { اذاخرج ثنا ثنة في سفر فليؤمروا احدهم }
$$

"Apabila tiga orang keluar dan dalam perjalanan, salah seorang di antara mereka hendaklah diangkat menjadi pemimpin"

Tentang kewajiban tersebut, di samping berlandaskan hadith di atas, Ibnu Taimiyyah juga berdasarkan pada salah salah satu hadith yang berbunyi:

$$
\text { لايحل لثنا ثنة يكونون بفلاة من الارض الا امروا عليهم احدهم }
$$

"Tidak halal bagi tiga orang yang berada dalam satu tempat kecuali salah seorang di antara mereka diangkat menjadi pemimpin"

Ketika mengomentari hadith tersebut, ia berkata,"Nabi Muhammad SAW. mewajibkan mengangkat pemimpin meskipun jumlah penduduk yang dipimpinnya sedikit seperti dalam perjalanan. Itu merupakan tanbih bahwa berbagai masyarakat diwajibkan mempunyai pemimpin, karena Allah memerintahkan kita untuk amar ma'ruf nahi munkar, jihad, menegakkan keadilan, menolong yang teraniaya, dan menegakkan hudud. Perintah-perintah tersebut tidak dapat dijalankan secara sempurna kecuali dengan kekuatan dan pemerintahan."

Dalam pandangnnya, pemimpin adalah bayang-bayang atau wakil Tuhan di bumi. Di samping itu, menurutnya keberadaan pemimpin yang tidak adil lebih maslahat daripada terjadi kekosongan pemimpin. ${ }^{31}$

c. Larangan jual beli dengan tujuan ma'siat ${ }^{32}$

Seperti yang kita ketahui bahwa akad akan menjadi sah apabila rukun dan syaratnya terpenuhi. Namun salah seorang yang berakad kadang-kadang menjadikan akad itu sebagai suatu alat untuk kepentingan pribadi yang keluar dari syara', tapi tidak haram, hanya mubah. Apakah akad itu sah karena rukunnya lengkap, yaitu ada ijab dan qabul? Atau tidak sah sebab untuk tujuan yang tidak disyari'atkan?.

Abu Hanifah menganggap akad ini sudah sah, sebab sudah ada ijab dan qabulnya. Niat tujuan yang tidak diperbolehkan menurut syara' sifatnya abstrak, dan hanya Allah yang mengetahui. Pendapat Abu Hanifah

31 Ibid., hlm. 174-175.

32 Muhammad Yusuf Musa, Ibnu Taimiyyah, (Kairo: al-Mu'assasah al-Masriyah al'Āmmah,1962), hlm. 230-232. 
ini pun disetujui oleh imam Syafi'i.Namun menurut imam Ahmad bin Hanbal, akad itu tidak sah meskipun ijab dan qabulnya sudah lengkap, sebab tujuan akad dari jual beli itu sudah diketahui. Pendapat ini disetujui oleh Ibnu Taimiyyah.

Bagi pendapat yang pertama (Abu Hanifah dan Syafi'i), jual beli bahan-bahan pembuatan arak atau minuman keras diperbolehkan. Tapi bagi pendapat yang kedua (Ahmad dan Ibnu Taimiyyah) tidak sah.Pendapat yang diikuti oleh Ibnu Taimiyyah tampaknya lebih bersifat preventif dari terjangkitnya penyakit sosial yang ditimbulkan oleh akibat minuman keras. Hal ini sesuai dengan sabda Nabi bahwa segala sesuatu itu bergantung pada niatnya.

Menurut al-Thahawi, kalau seseorang mempunyai bahan pembuat minuman keras boleh dijual. Namun dia hendaknya jangan menjualnya kepada orang yang biasa membuat arak, sebab bahan pembuat arak itu tidak diharamkan, maka menjualnya pun halal, yang penjualnya tidak mengetahui atau ada tanda-tanda pada pembeli bahwa dia ingin membuat sesuatu yang haram dengan bahan belian itu.

Dari uraian di atas dapat disimpulkan bahwa, dalam mengambil sebuah keputusan Ibnu Taimiyyah lebih menekankan kepada kemaslahatan umat.

\section{Gerakan Wahabi}

Gerakan ini dinisbahkan kepada Muhammad bin Abdul Wahab, seorang yang merasa betapa jauhnya kesesatan, bahkan kemusyrikan, pada prilaku keagamaan umat Islam saat itu (abad ke-18). Gerakan ini bertujuan untuk memurnikan prilaku keagamaan umat Islam yang telah menyimpang dari tuntunan agama yang sebenarnya.

Istilah Wahabi ini sebenarnya diberikan oleh musuh-musuh aliran ini. Pengikut Abdul Wahab sendiri menyebut diri mereka dengan nama alMuslimun atau al-Muwahhidun, yang artinya pendukung ajaran yang memurnikan ketauhidan Allah. Mereka juga menyebut diri mereka sebagai pengikut madzhab Hanbali. ${ }^{33}$

Inti ajaran yang dibawa oleh Abdul Wahab sangat dipengaruhi ajaran-ajaran yang dibawa oleh Ibnu Taimiyyah. ${ }^{34}$ Cara persuasif yang dilakukan Ibnu Taimiyyah dalam mencetuskan ajarannya dirasakan tidak

\footnotetext{
${ }^{33}$ Dewan Redaksi Ensiklopedi Islam, Ensiklopedi Islam, (Jakarta : PT Ichtiar Baru van Hoeve, 2000), hlm. 156.

${ }^{34}$ Ibid., hlm. 157.

354 JURNAL LISAN AL-HAL
} 
efektif oleh Abdul Wahab. Maka ia mengambil sikap keras dengan menggunakan kekuatan.

Ada dua inti ajarannya. Pertama, kembali kepada ajaran yang asli. Maksudnya adalah ajaran Islam yang dianut dan dipraktekkan oleh Nabi Muhammad, sahabat, dan para tabi'in. kedua prinsip yang berhubungan dengan tauhid. Menurutnya, orang yang menyembah selain Allah telah menjadi musyrik dan boleh dibunuh. Hal-hal yang termasuk syirik adalah meminta pertolongan bukan lagi kepada Allah tetapi kepada syaikh, wali, atau kekuatan gaib. ${ }^{35}$

Pada tahun 1804 dan 1806, gerakan Wahabi ini hampir pudar karena raja kerajaan Usmani, sultan Mahmud II, memberikan perintah kepada Muhammad Ali di Mesir, supaya mematahkan gerakan Wahabi itu. Akan tetapi, tidaklah berarti ajaran Wahabi ikut melemah pula. Ternyata, ajaran itu menyebar ke berbagai Negara seperti India, Sudan, Libya, dan Indonesia. Di arab Saudi sendiri gerakan Wahabi itu mulai bangkit kembali pada permulaan abad ke-20. Penyokongnya, Abdul Aziz Ibnu Sa'ud, dapat menduduki Makkah pada tahun 1924, setahun kemudian juga Madinah dan Jiddah. Sejak itu aliran dan kekuatan politik Wahabi mempunyai kedudukan yang kuat di Arab.

Dengan demikian, dapat diketahui bahwa aliran gerakan Wahabi itu lebih tegas dan lebih keras daripada gerakan Ibnu Taimiyyah dalam hal jihad fi sabilillah terutama melawan para ahli bid'ah dan khurafat.

\section{Kesimpulan}

Ibn Taimiyyah adalah seorang pembaharu dan pemurni Islam abad pertengahan yang memiliki otoritas tinggi. Metode berfikirnya adalah metode salaf yang bersumber pada al-qur'an dan hadis. Hukum-hukum fiqh yang ia istinbatkan seringkali bersandar kepada imam madzhabnya, yaitu imam Ahmad bin Hanbal. Metode ushul fiqh atau pemikiran hukum Islam Ibnu Taimiyyah adalah al-qur'an dan hadis, ijma', qiyas, istishab, dan mashlahah mursalah.

Pemikiran-pemikiran Ibn Taimiyyah dapat diklasifikasikan menjadi tiga macam, yaitu: pemikiran yang sama dengan Imam Ahmad bin Hanbal, pemikiran yang tidak mencirikan suatu madzhab tertentu tapi menurut pemikiran Ibnu Taimiyyah sendiri, dan pemikiran yang bertentangan dengan pendapat-pendapat keseluruhan Imam madzhab Islam.

Beberapa pendapat dan pemikiran hukum Islam Ibnu Taimiyyah yang terjadi pro dan kontra di antaranya adalah: Kedewasaan sebagai

${ }^{35}$ Ibid., hlm. 158. 
penghapus hak ijbar, pengangkatan pemimpin termasuk kewajiban agama, dan larangan jual beli dengan tujuan ma'siat

Salah satu gerakan Islam yang hampir sama dengan gerakan Ibnu Taimiyyah adalah gerakan Wahabi, akan tetapi gerakan Wahabi itu lebih tegas dan lebih keras daripada gerakan Ibnu Taimiyyah dalam hal jihad fi sabilillah terutama melawan para ahli bid'ah dan khurafat.

\section{DAFTAR PUSTAKA}

Dahlan, Abdul Azis dkk, Ensiklopedi Hukum Islam, Jakarta: PT Ichtiar Baru van Hoeve, 2003.

Dewan Redaksi Ensiklopedi Islam, Ensiklopedi Islam, Jakarta : PT Ichtiar Baru van Hoeve, 2000.

Jalil, Muhammad Sayyid, al-Imam Ibnu Taimiyyah wa Mauqifuhu Min Qodiyati al-Ta'wil, Kairo: al-Jam'iyah al-'Ammah li Shu'uni alMatabi' al-Amiriyah, 1972.

Madjid, Nur Cholish, Kaki Langit Peradaban Islam, Jakarta: Paramadina, 1997.

Masyhud, "Pemikiran Ibnu Taimiyah Tentang Metode Penafsiran Al-Qur'an Sebagai Upaya Pemurnian Pemahaman Terhadap Al-Qur'an", Jurnal Penelitian Agama,Vol. 9 No. 2. Januari, 2009.

Mubarok, Jaih, Sejarah dan Perkembangan Hukum Islam, Bandung: PT Remaja Rosdakarya, 2000.

Musa, Muhammad Yusuf, Ibnu Taimiyyah Kairo : al-Mu'assasah almasriyah al-'Ammah, 1962.

Nadwi, al-, Abu al-Hasan Ali al-Husni, Rijal al-Fikr wa al-Da'wah fi al-Islam, Kuwait: Dar al-Qalam, 1983.

Shaukani, al-, Muhammad ibn Ali, Nail al-Ausar Sharh Muntaq al-Akhbar, Juz 1, Beirut: Dar al-Jail, 1995.

Sjaddzali, Munawir, Islam dan Tata Negara, Jakarta: UI-Press, 2003.

Thaha, Ahmadie, Ibnu Taimiah Hidup dan Pemikirannya, Surabaya: PT Bina Ilmu Offset, 2007.

Zahrah, Muhammad Abu, Ibnu Taimiyyah Hayatuhu wa 'Ashruhu, Arauh wa Fiqhuh, Kairo: Dar al-Fikr , 2000.

,Tarikh al-Madzahib al-Fiqhiyyah, Kairo: Ma'had al-Dirasat alIslamiyyah, tt.

356 JURNAL LISAN AL-HAL 
